ISSN 2413-0877 Volume 2 (2015) 422-426

The 3rd International Conference on Biological Science 2013

(The 3rd ICBS-2013)

\title{
BIOACTIVITIES OF MAHONI'S (Swietenia mahagoni (L.) Jacq.) SEED ETHANOLIC EXTRACT ON THE PARASITEMIC LEVEL OF Plasmodium berghei IN MICE Mus musculus
}

\author{
Rr. Upiek Ngesti Wibawaning Astuti, Imam Fathoni, Tanti Rahayu, and \\ Ahmad Rizki Prasetyo \\ Faculty of Biology Universitas Gadjah Mada \\ upiekastuti@ugm.ac.id
}

\begin{abstract}
Bioactivities evaluation of mahoni's seed ethanolic extract on the parasitemic level of Plasmodium berghei have conducted in Parasitology laboratory Universitas Gadjah Mada. Peter's four days test (1970) was used in this research. There were 27 of mice and randomly was devided into 9 groups, 3 mice of each groups. There were 4 groups of controls: control with extract only, control with $P$. berghei infection only, control with $P$. berghei infection and chloroquin, and placebo. The other 5 groups of treated mice were mice treated with extract at the dose 5,$75 ; 12.5 ; 25 ; 50$; and100 mg/kg of body weight. Results showed that saponin and terpenoid were detected as bioactive compound. Mahoni's seed extract at the dose $50 \mathrm{mg} / \mathrm{kg}$ of body weight gave the good effectivness in reducing the parasite up to $60 \%$ compare with control + chloroquin.
\end{abstract}

Key words: Plasmodium berghei, Swietenia mahagoni, parasitemic level, mice

\section{INTRODUCTION}

Malaria is still as main health problem in the world and it is in the $2^{\text {nd }}$ place of infection cases after HIV/AIDS (CDC, 2012). In Indonesia, more than 107 million of people live in endemic areas, and it had reported that in the year of 2006-2008 there were more than 2,5 million malaria cases and 3.480 of people was death (Anonim, 2008). There are many efforts to overcome this disease including development of drugs, vaccine, even for control the mosquitoes as vector. However, it was reported that the parasite and vector have been resistant, this may because of the results from the using of continuous and longterm drugs, or insecticides.

Malaria is as one of tropical diseases and it is caused by infection of Plasmodium. This infection may produce paraxysm and if this happen continously in the periods of time it may cause anemia. There were 4 agent protozoan parasite that cause malaria, namely Plasmodium vivax, Plasmodium falciparum, Plasmodium ovale, and Plasmodium malariae (Levine, 1995). Plasmodium berghei that used in this study has dynamic mode of infection similarly with $P$. falciparum that may cause severe malaria. This parasite have similarly in the morfology, physiologic and life cycle. Actually, this parasite may infect the rodents (Janse and Waters, 2007).

Up to now, the drugs still have low effects, especially in the endemic areas. Discovery for new or candidate drugs has been develop. Researcher has been looking from the natural product that may contribute to reduce the level of infection. A lot of plants have been searching for their secondary metabolite that may play role for the candidate of natural drugs against malaria. Mindi's (Melia azadirachta) seed, Carica papaya, patikan kebo (Euphorbia hirta), bark of mundu (Garcinia dulcis Kurz) for example, have been tested for antimalaria 
(Poerwanto et al, 2000; Widodo and Rahayu, 2010; Astuti et al.,2013).

There were alkaloids, flavonoids, saponin, terpenoids, and steroids may as bioactive compound in the plants (Herbert,1995; Saxena,2003). Alkaloid and flavonoid have biological activities in development of Plasmodium (Saxena, 2003). Flavonoids 147 dan 148 had been isolated from Neoraputia magnifica (Rutaceae), and flavonoid 149 had isolated from Lonchocarpus subglaucescens (Leguminosae), these plants has positive effects against $P$. falciparum. Other compound, other flavonoid: flavone 3-methoxycarpachromene that had been isolated from Pistacia atlantica also shown the positive activities in malaria falciparum (Nogueira \& Lopes, 2011).

Swietenia mahagony is an annual plant, originally from tropical America, with the height up to 5,25 m, the seed was flat and dark-brown in colour (Harianja, 2008). Mahoni has been planted near housing or offices as canopy plants. For resident, mahoni's seed was used for reducing blood pressure, anti fungi, fever, glucose levels, and rheumatic. The bark of mahoni can be used for reducing fever, and it can be made as tonicum and astringent (Harianja, 2008). This plant soundly gave a lot of benefits in reducing disease. However, there was lack information for the using of mahoni (S. mahagoni) seed or other parts of this plant for reducing malaria infection. Based on this, we would like to explore what is the kind of mahoni's seed bioactive compounds and how is the effects against Plasmodium.

The objectives of this research were to determine the bioactives compound of mahoni's seed ethanolic extract and effects of extract on the parasitemic level of Plasmodium berghei in mice.

\section{METERIALS AND METHODS}

The research design was experimental study with methods Completely Randomized Design (CRD) for bioassay and Peter's 4 days Test (1970) for testing the mahoni's seed extract in mice. This research was conducted at the Laboratory of Parasitology Faculty of Biology Universitas Gadjah Mada.

Plasmodium berghei isolat was take from the pure culture that was from infected mice. This culture was prepared in the Laboratory of Parasitology Faculty of Medicine UGM. Twenty seven of mice were in 2-3 months old, 20-30 gr in weight were used in this study. This mice were devided into 9 groups, 3 mice of each groups, 4 groups of control and 5 groups of treted mice, in detailed as shown in table 1.

Mahoni's seed extract was made by using maseration method at the Integrated Laboratory and Research (LPPT) of UGM. In bioassay, the concentration of $6.25 ; 12.5 ; 25 ; 50$; and $100 \mathrm{mg} / \mathrm{Kg} \mathrm{BW}$ of extract were used for control and treated mice. The study for tracing the bioactive compounds was made in LPPT and in the Laboratory of Biochemistry Faculty of Biology UGM. The Chromatography Thin Layers methods was used to detect the compound in mahoni's seed.

Each control $\left(\mathrm{K}_{+}, \mathrm{K}_{++}\right)$and treated mice on the day $0(\mathrm{H}-0)$ were peritoneally infected with $10^{7}$ of $P$. berghei diluted into $0.2 \mathrm{ml}$ of blood. For other control groups (K-and $\mathrm{K}-$ ) were natural saline injection perinoneally at the same volume. In the first day $\left(1^{\text {st }}, \mathrm{H}-1\right)$ to fourth day $\left.\left(4^{\text {th }}, \mathrm{H}-4\right)\right)$ all treated mice and $\mathrm{K}$ - were given extract at diferent concentration depends on groups (Table 1$)$. In the fifth day $\left(5^{\text {th }}\right)$ all of mice were sacrificed and other studies were 
made. From the $1^{\text {st }}$ day up to $5^{\text {th }}$ day of test the tail blood were collected and made into slides (3 slides of each mice, each day), and the body weight was measured and tabulized.

Slides were then stained with Giemsa's stain, and just leave in the room temperature for driying. All slides were identified, the level of parasite was calculated by using hand tally counter. The number of parasites in 1000 of red blood cells from slides were counted, and the data was tabulized. Data were analized by descriptive analisys and statistical method by using one-way ANOVA for the total number of parasite from each groups of mice.

Table1. Groups of control and treated mice with mahoni's seed ethanolic extract

\begin{tabular}{lllcc}
\hline No & groups & $\begin{array}{c}\text { Concentration of } \\
\text { extract }\end{array}$ & $\begin{array}{c}\text { Treatment } \\
\text { DMSO }\end{array}$ & $\begin{array}{c}\text { Treatment } \\
\text { P. berghei/0.2 m/ blood }\end{array}$ \\
\hline 1 & $\mathrm{~K}(-)$ & - & + & - \\
2 & $\mathrm{~K}(--)$ & Ekstrak 25 mg/Kg & - & - \\
3 & $\mathrm{~K}+$ & - & - & + \\
4 & $\mathrm{~K}(++)$ & Klorokuin & - & + \\
& & $5 \mathrm{mg} / \mathrm{kg} \mathrm{BW}$ & + & + \\
5 & PE1 & $6.25 \mathrm{mg} / \mathrm{kg} \mathrm{BW}$ & + & + \\
6 & PE2 & $12,5 \mathrm{mg} / \mathrm{kg} \mathrm{BW}$ & + & + \\
7 & PE3 & $25 \mathrm{mg} / \mathrm{kg} \mathrm{BW}$ & + & + \\
8 & PE4 & $50 \mathrm{mg} / \mathrm{kg} \mathrm{BW}$ & + & + \\
9 & PE5 & $100 \mathrm{mg} / \mathrm{kg} \mathrm{BW}$ & + & + \\
\hline
\end{tabular}

\section{RESULTS AND DISCUSSION}

By using Thin Layer Chromatography' at the wave of UV 254 and 365, and the visible wave there were no flavonoid to be detected, as shown in figure 1.
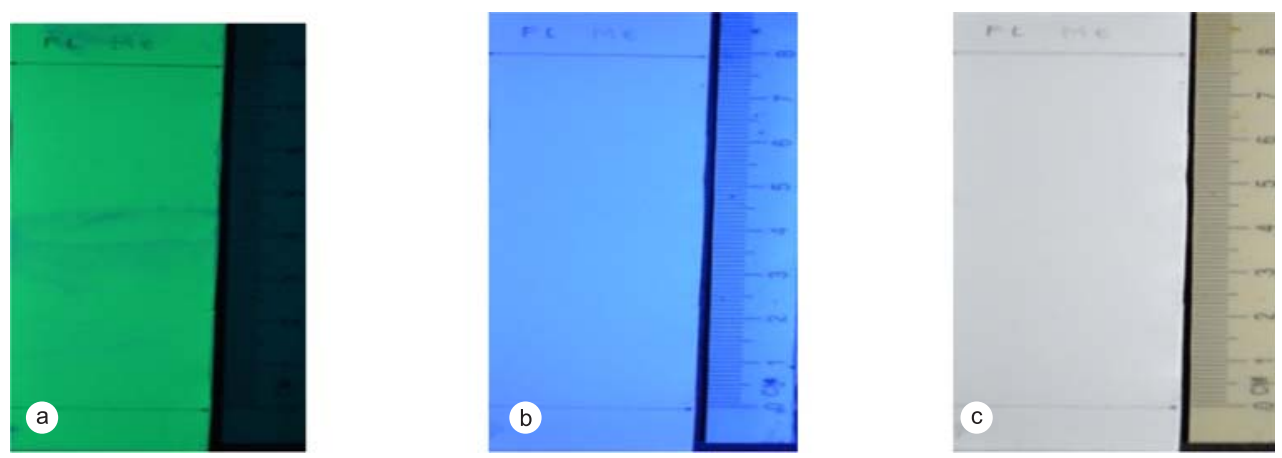

Figure 1. Results of flavonoids detection by using Thin Layer Chromatography at the wave: (a)UV 254, (b)UV 365, (c) UV visibel (Doc. LitKDM, 2012).

For the saponin and terpenoid compounds, at the same wave, it can be detect that there were positive results of both compounds in mahoni's seed (Fig.2).

As shown in figure 3 there was terpenoid can be detected from mahoni's seed extract, with the three wave gave the $\mathrm{Rf}$ value were 0,$19 ; 0,44 ; 0,68$; and 0,96 respectively. It can be assumed that both compounds, especially terpen had effects to parasite, $P$. berghei. As Goulart et al. (2004) and Su et al (2008) said that terpen/ monoterpen can be inhibit the biosynthesis of isoprenoids on Plasmodium falcipharum. However, it should be carefull and in a good control and monitor for the periode of time and concentration in the using of 

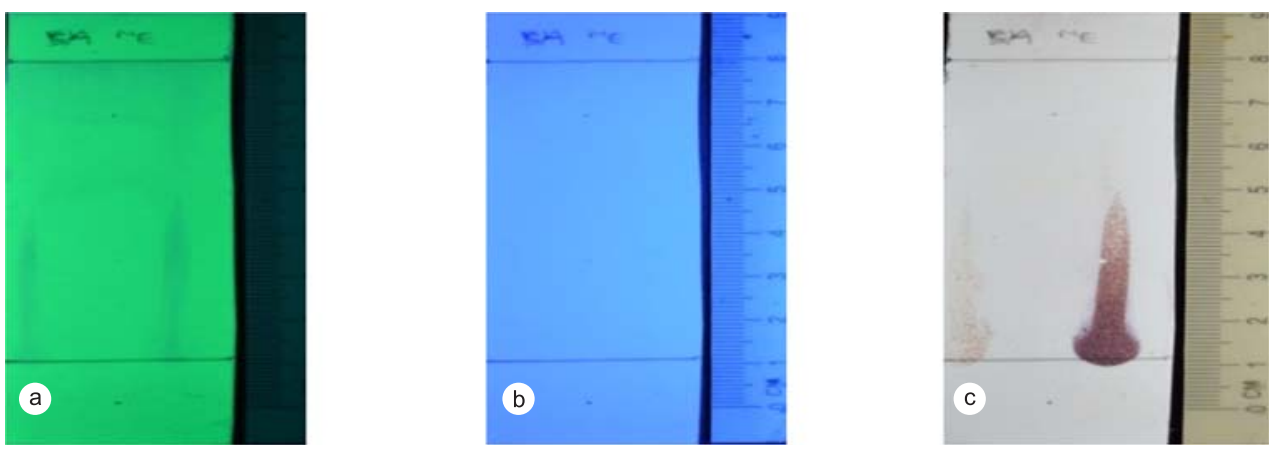

Figure 2. Positive results of saponin compound from the mahoni's seed extract by using Thin Layer Chromatography. (a)UV 254, (b)UV 365, (c) UV visibel (Doc. LitKDM, 2012).
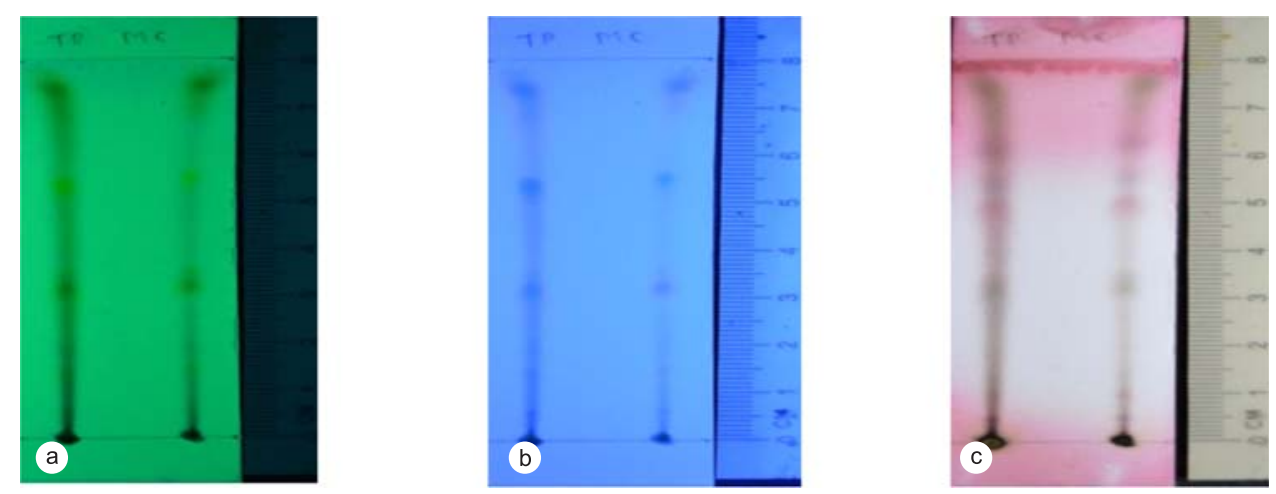

Figure 3. Positive results of terpenoid compound from the ethanolik extract of mahoni 's seed by using Thin Layer Chromatography, at the wave: (a)UV 254, (b)UV 365, (c) UV visibel (Doc. LitKDM, 2012).

terpen as the alternative drugs for malara, because this compound has side negative effects on the red blood cells. For future, it should be redetect of flavonoids from this part of plant, because this compound has antibacteriall activities in some previous research.

There was variation in the parasitemic level from the $3^{\text {rd }}$ and $5^{\text {th }}$ day of treatment, as shown in Table 2. Figure 4 showed the detailed of effectiveness of mahoni's seed extract against parasite.

At the concentration of 25 and $50 \mathrm{mg} / \mathrm{KG} \mathrm{BW}$ showed gave the good extract tolerabilities if compared with the control+chloroquin. It was assumed that the extract may have positive results in reducing the parasitic level or in other way can it says that the extract may be used as alternative drugs for malaria.

\section{CONCLUSIONS}

1. Saponin and terpenoid as bioactive compounds were detected in the mahoni's seed extract.

2. Mahoni's seed extract at the dose $50 \mathrm{mg} / \mathrm{kg}$ of body weight gave the good effectivness in reducing the parasite up to $60 \%$ compare with control + chloroquin. 


\section{ACKNOWLEDGEMENT}

1. DGHE for the supporting fund to this study

2. LPPM UGM for the coordination

3. Head and staff of Parasitology Laboratory of The Faculty of Medicine UGM

4. Head and staff of Parasitology Laboratory of The Faculty of Biology UGM

\section{REFERENCES}

Anonim. 2008. Indonesia masih menjadi negara endemis tinggi malaria. http: // www.pdpersi.co.id. Accessed: 20 Desember 2009.

CDC. 2012. Malaria. http://www.cdc.gov/malaria/.Accessed 29 April 2012

Goulart, H.R., E.A. Kimura, V.J. Peres, A.S. Couto, F.A.A. Duarte, and A.M. Katzin. 2004. Terpenes arrest parasite development and inhibit biosynthesis of isoprenoids Plasmodium falciparum. Amer. Soc. For Micro. 48 (7): 2505-2509.

Harianja.2008.Mahoni dan Pemanfaataannya. http://www.bpdas pemalijratun.net/ index.php?option=com_content\&view=article\&id=61: mahoni \&catid=18:tanamanberkayu\&Itemid=31. Accessed: 29 April 2012

Harborne, J.B. 1987. Phytochemical Methods: A Guide to Modern Techniques of Plant Analysis. Chapman \& Hall Inc. London,

Herbert, R.B. 1995. Biosintesis metabolit sekunder. Trnaslated by: Bambang Srigandono. Semarang: IKIP Semarang Press.

Janse, C., and A. Waters. 2007. The Plasmodium berghei research model of malaria. www.lumc.nl/1040/research/malaria.model05.html . Accessed: : 29 April 2012

Levine, N.D. 1995. Protozoologi veteriner. Yogyakarta: Gadjah Mada University Press.

Nogueira, C. R., and L. M. X. Lopes. 2011. Antiplasmodial Natural Products. Molecules. 16: 2146-2190.

Peter, Y. 1970. Technique for study of drug response in experimental malaria chemotherapy and drug resistance in malaria. New York: Academic Press.

Saxena, S., N. Pant, D.C. Jain, and R.S. Bhakuni. 2003. Antimalarial Agents from Plant Sources. Curr. Sc. 85 (9): 1314-1329.

Su, V., D. King, I. Woodrow, G. McFadden, and R. Gleadow. 2008. Plasmodium falciparum growth is arrested by monoterpenes from eucalyptus oil. Flav. And Frag. Jou. (23): 315318.

Widodo, G.P., dan M. P. Rahayu. 2010. Aktivitas Antimalaria Ekstrak Etil Asetat Kulit Batang Mundu (Garcinia dulcis Kurz). Maj. Farm. Indo. 2 (4): 238 - 242 